\title{
IMPLEMENTASI TEORI DUALISTIS HUKUM PIDANA DI DALAM \\ RANCANGAN KITAB UNDANG-UNDANG HUKUM PIDANA (RKUHP)
}

\author{
Lukman Hakim \\ Universitas Bhayangkara Jakarta Raya \\ lukmanhakim33@gmail.com
}

\begin{tabular}{|c|c|c|}
\hline Naskah diterima: & Revisi: & Naskah disetujui: \\
$27 / 5 / 2019$ & $31 / 05 / 2019$ & $31 / 05 / 2019$ \\
\hline
\end{tabular}

\begin{abstract}
Abstrak
Sistem pemidanaan dalam KUHP didasarkan pada asas legalitas yang mensyaratkan bahwa pidana dapat dijatuhkan apabila terpenuhi syarat adanya perbuatan dan kesalahan, hal mana mengakibatkan pemidanaan dalam KUHP dirasakan sangat kaku dalam menyelesaikan problematika penegakan hukum, sementara dari asas legalitas ini telah bergeser menjadi asas atau teori dualistis yang memisahkan tindak pidana dan pertanggungjawaban pidana. RKUHP secara eksplisit telah mengimplementasikan teori dualistis ini sebagai bagian sistem pemidanaan, sehingga hubungan antara kepastian hukum dan keadilan dapat diwujudkan secara seimbang dalam putusan hakim.
\end{abstract}

Kata kunci: teori dualistis, hukum pidana.

\begin{abstract}
The penal system in the Criminal Code based on the Principle of Legality that requires a criminal sentence that can be imposed if the conditions for criminal act and guilty are met, hence the Criminal Code is consider to be rigid in solving law enforcement problems, the principle of legality has shifted into the principle or Theory of dualistic that separates criminal acts and criminal liability. RKUHP has explicitly implemented this dualistic theory as part of the criminal system, so that the relationship between legal certainty and justice can be realized in a balanced manner in the judge's verdict.
\end{abstract}

Keywords: dualistic theory, criminal law.

\section{PENDAHULUAN}

Perumusan Rancangan Kitab Undang-Undang Hukum Pidana (RKUHP) telah memasuki tahap akhir dalam pembahasannya. ${ }^{1}$ Perumusan ini antara lain didasarkan pada

\footnotetext{
${ }^{1}$ Tim Penyusun. "Naskah Rancangan Kitab Undang-Undang Hukum Pidana Hasil Pembahasan Panitia Kerja RKUHP-DPR RI”, 24 September 2018 (Jakarta: BPHN \& Menkumham, 2018), (selanjutnya disebut "RKUHP").
} 
Implementasi Teori Dualistis Hukum Pidana Di Dalam Rancangan Kitab Undang-Undang Hukum Pidana (RKUHP) Lukman Hakim

perlunya pembaharuan hukum pidana di Indonesia yang saat ini dihadapkan pada persoalan kriminalisasi sebagai akibat dinamika hukum pidana dalam kaitan dengan perubahanperubahan yang terjadi dalam masyarakat yang perlu mendapat pengamanan oleh hukum pidana. Dalam ruang lingkup politik kriminal, proses kriminalisasi merupakan suatu kebijakan dalam upaya penanggulangan kejahatan dengan menggunakan sarana hukum pidana sebagai alternatif, disamping masih menggunakan usaha-usaha yang tidak bersifat hukum pidana. Sebagaimana juga disampaikan oleh Curzon, "The legislature to leave unexpressed some of mental elements of crime...".2

Penggunaan hukum pidana sebenarnya tidak selalu merupakan keharusan, jika kegiatan preventif yang tidak bersifat hukum pidana masih mempunyai kedudukan yang strategis, bahkan memegang posisi kunci yang harus diintensifkan dan diefektifkan. ${ }^{3}$ Sehubungan hal ini, $\operatorname{Ross}^{4}$ juga menyatakan:

"Prevention, or more generally the influencing of behavior, is only adequate answer when the question is posed as one of aim of penal legislation. Retribution, i.e., requirement of guilt as a precondition and measure of punishment, is only adequate answer when the question is posed as one of what restrictive moral consideration limit the state's right to use as means of influencing behavior".

Disamping itu adanya pengaruh perkembangan dunia hukum pidana secara global, terutama setelah dilakukannya beberapa kali Kongres PBB tentang The Prevention of Crime and the Treatment of Offenders, wacana mengenai hukum pidana mengalami perombakan yang signifikan. Salah satu perkembangannya adalah orientasi pemidanaan yang lebih "memanusiakan" pelaku tindak pidana (offenders) dalam bentuk pembinaan (treatment). ${ }^{5}$ Berdasarkan perkembangan ini, maka pada saat usaha hukum pidana (materil) digalakkan, seharusnya Indonesia memperbaharui sistem pemidanaannya yang kaku dan imperatif tersebut menjadi sistem pemidanaan yang mengedepankan aspek kemanusiaan yang menjunjung tinggi keadilan.

Di dalam perkembangan teori pemidanaan dikaitkan dengan putusan hakim, dalam beberapa tahun belakangan mendapat kritikan yang cukup tajam dari para ahli hukum pidana. Karena tidak jarang putusan hakim justru dianggap bertentangan dengan makna

\footnotetext{
${ }^{2}$ L. B. Curzon. Criminal Law (London: M\&E Pitman Publishing, 1997), hlm. 23.

${ }^{3}$ Muladi, Barda Nawawi Arief. Teori-teori dan Kebijakan Pidana (Bandung: Alumni, 1984), hlm. 159.

${ }^{4}$ Alf Ross. On Guilt, Responsibility and Punishment (London: Stevens and Sons, 1975), hlm. 60-61.

5 "Prinsip-individualisasi-pidana", (On-line), tersedia di:http://ahmadbahiej.blogspot.co.id

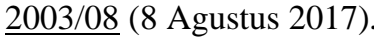


keadilan karena semata-mata putusan-putusan tersebut didasarkan kepada asas legalitas ${ }^{6}$ semata.

Sementara itu, dikaitkan dengan asas legalitas ini, dalam teori hukum pidana telah pula bergeser menjadi asas "tiada pidana tanpa kesalahan" atau asas dualistis dalam hukum pidana. ${ }^{7}$ Di mana pikiran-pikiran untuk memisahkan tindak pidana dari pertanggungjawaban pidana telah menjadi bagian pembaruan hukum pidana Indonesia. Ketentuan ini kemudian juga akan diadopsi dalam RKUHP.

Dikaitkan dengan teori dualistis di atas, maka dalam hal penjatuhan pidana, pengadilan bertugas memberikan pertimbangan secara seimbang antara tindak pidana dan pertanggungjawaban pidana pembuat tindak pidana sebagai dasar penjatuhan pidana. Di satu sisi, tindak pidana menegaskan kepentingan hukum masyarakat yang hendak dilindungi oleh norma hukum. Di sisi lain, kesalahan dan pertanggungjawaban pidana menekankan kepada kewajiban hukum yang didasarkan atas keadaan tertentu pada diri pembuat tindak pidana.

Dilatarbelakangi hal di atas, maka penulis mencoba menjelaskan mengenai teori dualistis yang sebelumnya tidak diatur secara eksplisit di dalam KUHP, namun nantinya sekalipun tidak juga disebut sebagai teori dualistis, maka akan diimplementasikan secara eksplisit di dalam RKUHP.

\section{PEMBAHASAN}

Pemikiran yang mewarnai cita rasa keadilan dalam pemidanaan memunculkan berbagai tujuan pemidanaan yang berkembang dari masa lalu ke masa sekarang yang lebih mengarah ke arah yang lebih rasional. Dimulai dari teori pembalasan (retributivism) sampai dengan teori kemanfaatan (utilitarianism) ${ }^{8}$ yang bertujuan memuaskan semua pihak.

\footnotetext{
${ }^{6}$ Asas Legalitas terdapat dalam KUHP, Pasal 1 ayat (1) yang berbunyi, "Suatu perbuatan tidak dapat dipidana, kecuali berdasarkan kekuatan ketentuan perundang-undangan pidana yang telah ada".

${ }^{7}$ Andi Hamzah. Asas-Asas Hukum Pidana (Jakarta: Penerbit Rineka Cipta, 2014), hlm. 98. Di Indonesia, ahli hukum pidana yang mempelopori pemisahan actus reus (perbuatan pidana) dan mens rea (pertanggungjawaban pidana) adalah Moeljatno, Roeslan Saleh, A.Z. Abidin dan Barda Nawawi Arief. Umumnya, para ahli hukum pidana yang menganut aliran dualistis ini memandang bahwa pandangan monoistis ini akan menimbulkan ketidakadilan dalam pelaksanaan hukum pidana di masyarakat. Selanjutnya Andi Hamzah menyatakan, pemisahan tersebut hanya penting diketahui oleh para penuntut umum dalam menyusun surat dakwaan, karena surat dakwaan, cukup berisi bagian inti (bestanddelen) delik dan perbuatan nyata terdakwa, jadi actus reus saja. Tidak perlu dimuat dalam surat dakwaan bahwa terdakwa dapat dipertanggungjawabkan (tidak menderita sakit jiwa).

${ }^{8}$ Herbert L. Packer. The Limits of The Criminal Sanction (Stanford California University: Stanford California Press, 1968), hlm.37-58. Menurut retribution theory (teori pembalasan), bahwa hakikat dan pembenaran dari pemidanaan adalah, pembalasan seseorang yang telah melakukan kejahatan harus dibalas dengan hukuman penderitaan yang setimpal sebagai tebusan dari kejahatan yang dilakukannya. Sementara menurut utilitarian theory (teori manfaat), bahwa hakikat dan pembenaran dari pemidanaan itu adalah terletak pada manfaat bagi si pelaku kejahatan agar ia tidak berbuat lagi, disamping bermanfaat terhadap orang lain/masyarakat guna mencegah asuransia supaya tidak melakukan kejahatan.
} 
Implementasi Teori Dualistis Hukum Pidana Di Dalam Rancangan Kitab Undang-Undang Hukum Pidana (RKUHP) Lukman Hakim

Di dalam KUHP yang sekarang berlaku, tidak semua bangunan/konstruksi konsepsional sistem hukum pidana atau ajaran hukum pidana umum itu dirumuskan di dalam Bagian Umum Buku I. Antara lain ketentuan mengenai tujuan dan pedoman pemidanaan, pengertian/hakikat tindak pidana, sifat melawan hukum (termasuk asas tiada pertanggungjawaban pidana tanpa sifat melawan hukum/no liability without unlawfullness, asas ketiadaan sama sekali sifat melawan hukum secara material atau dikenal dengan asas afwezig-heids van alle materiele wederrechtelijkheid (AVAS). ${ }^{9}$

Walaupun ajaran umum atau konstruksi konsepsional yang umum sebagaimana di atas tidak ada di dalam KUHP, tetapi semua itu ada di dalam pelajaran hukum pidana yang diajarkan kepada mahasiswa fakultas hukum. Seringkali konstruksi konsepsional yang umum itu dilupakan, bahkan kemungkinan tidak digunakan dalam praktik atau proses dalam penjatuhan putusan di pengadilan, hanya karena tidak ada perumusannya secara eksplisit di dalam KUHP. Padahal dilihat dari sudut sistem, posisi tujuan pemidanaan sangat sentral dan fundamental. Tujuan pemidanaan inilah yang merupakan jiwa dari sistem pemidanaan.

Pada masanya, Moeljatno ${ }^{10}$ pada tahun 1955 dalam pidato pengukuhan sebagai guru besar hukum pidana di Universitas Gajah Mada, telah mengemukakan pandangannya mengenai asas "tiada pidana tanpa kesalahan" (Geen straf zonder schuld, actus non facit reum nisi mens sist rea) atau yang lebih dikenal dengan asas dualistis. Asas ini tidak tersebut dalam hukum tertulis tapi terdapat dalam hukum yang tidak tertulis yang juga di Indonesia berlaku. Pada pokoknya ajaran ini memisahkan tindak pidana dan pertanggungjawaban pidana. Tindak pidana merujuk pada dilarangnya perbuatan dan tidak termasuk pertanggungjawaban.

Dinyatakan oleh Moeljatno, bahwa "perbuatan pidana hanya menunjuk kepada sifat perbuatan saja, yaitu sifat dilarang dengan ancaman pidana kalau dilanggar." ${ }^{11}$ Selanjutnya Moeljatno menyatakan, ${ }^{12}$ perumusan tindak pidana hanya memuat tiga hal, yaitu subjek

\footnotetext{
9 Tim Penyusun. "Naskah Akademis Rancangan Kitab Undang-Undang Hukum Pidana (RKUHP) Edisi 25 Februari 2015". (Jakarta: BPHN \& Menkumham, 2015), hlm. 20. (Selanjutnya disebut "Naskah Akademis RKUHP").

${ }^{10}$ Moeljatno. "Perbuatan Pidana dan Pertanggungjawaban Dalam Hukum Pidana". (Pidato Ilmiah dalam Dies Natalis Universitas Gajah Mada, pada tanggal 19 Desember 1955). Lihat juga, Moeljatno, Asas-Asas Hukum Pidana, Op.Cit., hlm. 165. Menurut Moeljatno, "Perbuatan pidana hanya menunjuk kepada dilarang dan diancamnya perbuatan dengan suatu pidana. Apakah orang yang melakukan perbuatan kemudian juga dijatuhi pidana, sebagaimana yang diancamkan, ini tergantung dari soal apakah dalam melakukan perbuatan ini dia mempunyai kesalahan. Sebab asas dalam pertanggungjawaban dalam buku ini ialah: Tidak dipidana jika tidak ada kesalahan (Geen straf zonder schuld). Asas ini tidak tersebut dalam hukum tertulis tapi dalam hukum yang tidak tertulis yang juga di Indonesia berlaku".

${ }^{11}$ Moeljatno, Asas-asas Hukum Pidana, Op.Cit., hlm. 56-57.

${ }^{12}$ Moeljatno, Perbuatan Pidana dan Pertanggungjawaban dalam hukum Pidana, Op.Cit., hlm. 11.
} 
delik yang dituju oleh norma hukum (normaddressaat), perbuatan yang dilarang (strafbaar), dan ancaman pidana (strafmaat). Ketiga hal ini merupakan masalah kriminalisasi yang termasuk dalam lingkup tindak pidana. Sebaliknya pertanggungjawaban pidana hanya mempersoalkan segi-segi subjektif dari pembuat tindak pidana. Dalam tahap ini, persoalan tidak lagi berkisar pada masalah perbuatan dan sifat melawan hukumnya, melainkan berkaitan dengan dalam keadaan bagaimanakah pembuat dapat dipertanggungjawaban atas tindak pidana.

Menurut Edward Omar Sharif Hiarij, setelah apa yang disampaikan Moeljatno tersebut, maka merubah sistem hukum pidana di Indonesia, baik secara praktek maupun teoritis. ${ }^{13}$ Sekalipun asas ini tidak dipraktekkan secara massif di dalam praktek hukum pidana dan tidak diterapkan dalam KUHP, namun setelah melalui proses yang cukup panjang dan dengan dimasukkannya asas ini secara eksplisit di dalam RKUHP yang akan datang, maka dapat dikatakan bahwa asas ini akan kembali ke "rumahnya" lagi.

Sejalan dengan pandangan Moeljatno, menurut Roeslan Saleh, ${ }^{14}$ melakukan suatu tindak pidana, tidak selalu berarti pembuatnya bersalah atas hal itu. Untuk dapat mempertanggungjawabkan seseorang dalam hukum pidana diperlukan syarat-syarat untuk dapat mengenakan pidana terhadapnya, karena melakukan tindak pidana tersebut. Dengan demikian, selain telah melakukan tindak pidana, pertanggungjawaban pidana hanya dapat dituntut ketika tindak pidana dilakukan dengan 'kesalahan'. Dalam memaknai 'kesalahan', Roeslan Saleh menyatakan, ${ }^{15}$ 'Kesalahan' adalah dapat dicelanya pembuat tindak pidana, karena dilihat dari segi masyarakat sebenarnya dia dapat berbuat lain jika tidak ingin melakukan perbuatan tersebut.

Sementara Moeljatno dengan meminjam pendapatnya dari Simons menyatakan, 'Kesalahan' adalah adanya keadaan psikis yang tertentu pada orang yang melakukan perbuatan pidana dan adanya hubungan antara keadaan tersebut dengan perbuatan yang dilakukan yang sedemikian rupa, hingga orang itu dapat dicela karena melakukan perbuatan tadi. Bahwa untuk adanya kesalahan harus dipikirkan dua hal disamping melakukan perbuatan pidana. Pertama: adanya keadaan psikis (batin) yang tertentu, dan Kedua: adanya hubungan yang tertentu antara keadaan batin tersebut dengan perbuatan yang dilakukan, hingga menimbulkan celaan tadi. Sungguh pun antara yang pertama dan yang kedua ada

\footnotetext{
13 (On-line), tersedia di:http://firmanhakim03.blogspot.com/2016/09/rangkuman-keterangan-ahlipidana-prof26-html (7 Oktober 2017).

${ }^{14}$ Roeslan Saleh. Perbuatan Pidana dan Pertanggungjawaban Pidana; Dua Pengertian Dasar dalam Hukum Pidana (Jakarta: Aksara Baru, 1983), hlm. 89.

${ }^{15}$ Ibid., hlm. 77.
} 
Implementasi Teori Dualistis Hukum Pidana Di Dalam Rancangan Kitab Undang-Undang Hukum Pidana (RKUHP) Lukman Hakim

hubungan yang erat, bahkan adanya yang pertama merupakan dasar bagi adanya yang kedua atau yang kedua tergantung dari yang pertama, namun untuk jelasnya baiklah dalam teori dipisahkan yang satu dan yang lain. ${ }^{16}$

Menurut Barda Nawawi Arief, ${ }^{17}$ bahwa tindak pidana hanya membahas perbuatan secara objektif, sedangkan hal-hal yang bersifat subjektif terkait dengan sikap batin pembuat tindak pidana harus dikeluarkan dari pengertian tindak pidana, karena sikap batin pembuat termasuk dalam lingkup kesalahan dan pertanggungjawaban pidana yang menjadi dasar etik dapat dipidananya pembuat. Menurut William, "the act constituting a crime may in some circumstances be objectively innocent". ${ }^{18}$

Dari sini terlihat perbedaan tindak pidana dan pertanggungjawaban pidana. Tindak pidana hanya berorientasi pada perbuatan yang dilarang berdasarkan norma hukum, sedangkan pertanggungjawaban pidana menunjuk kepada sikap-sikap subjektif yang didasarkan kepada kewajiban hukum seseorang untuk mematuhi hukum. ${ }^{19}$ Fletcher menyatakan "we distinguish between characteristic of the actor...". ${ }^{20}$ Secara konseptual, Fletcher menjelaskan bahwa hukum pidana mempunyai dua norma. Pertama, norma hukum yang mengatur perbuatan tertentu yang dilarang atau diperintahkan, "the basic norm of the criminal law prohibit particular acts or require the particular acts be performed". ${ }^{21}$ Norma dasar ini merupakan tatbestandmabigkeit yang memuat seperangkat unsur-unsur tindak pidana dalam peraturan hukum secara komprehensif yang mengandung berbagai jenis kejahatan. ${ }^{22}$ Dengan kata lain, tindak pidana menekankan kesesuaian perbuatan tertentu dengan rumusan delik.

Kedua, norma yang menggambarkan tentang keadaan tertentu yang menyebabkan pembuat tindak pidana dapat dicela atas tindak pidana yang dilakukan. Dikatakan bahwa "the analysis of attribution turns our attention to a totally distinct set of norms, which do not provide directives for action, but which spell out the criteria for holding persons

\footnotetext{
${ }^{16}$ Moeljatno, Asas-asas Hukum Pidana, Op.Cit., hlm. 171.

${ }^{17}$ Barda Nawawi Arief. Kapita Selekta Hukum Pidana (Bandung: Citra Aditya Bakti, 2013), hlm. 107. Menurut Barda Nawawi Arief, konsepsi ini digunakan dalam RKUHP.

${ }^{18}$ Glanvile William. Criminal Law: Generel Part (London: Stevens \& Sons, 1961), hlm. 22.

${ }^{19}$ Roeslan Saleh. Masih Saja tentang Kesalahan (Jakarta: Karya Dunia Fikir, 1994), hlm. 81-82.

${ }^{20}$ George P. Fletcher. Rethinking Criminal Law (New york: Oxford University Press, 2000) hlm. 455. Lihat juga Albin Eser. "Justification and Excuses" 24. (The American Juornal of Comparative Law, 1976), hlm. 628. Pembagian norma yang diungkapan George P. Fletcher berasal dari teori norma yang dikembangkan oleh Beling. Menurut teori ini, norma dibagi menjadi norma hukum (legal norm) dan norma pertanggungjawaban pidana (norm of responsibility).

${ }^{21}$ Ibid., hlm. 456.

${ }^{22}$ Ernest Ludwig von Beling. Lehre vom Verbrechen (Tubingen: JCB Mohr, 1906), tanpa halaman.
} 
accountable for their deeds. "23 Analisis tentang pertanggungjawaban pidana merupakan ketentuan berbeda yang tidak menunjuk kepada perbuatan, tetapi berkaitan dengan penentuan kriteria seseorang yang dapat dipertanggungjawabkan atas perbuatannya.

Pemisahan tindak pidana dan pertanggungjawaban pidana bertujuan untuk mempertegas fungsi-fungsi hukum pidana, sehingga dapat dimengerti oleh masyarakat luas sebagaimana diungkapkan oleh Paul H. Robinson, "to be effective, the rules of conduct must be simple, based on objective criteria with easily communicable and comprehensible standard." 24 Di sisi lain, pertanggungjawaban pidana menekankan fungsi adjudikasi yang memberikan pedoman bagi hakim untuk menentukan keadaan-keadaan tertentu yang menjadi dasar dapat dipertanggungjawabkannya pembuat dan oleh karenanya dapat dipidana. ${ }^{25}$

Menurut hemat penulis, dengan dipisahkannya tindak pidana dan pertanggungjawaban pidana sebagaimana di atas, menyebabkan kesalahan dikeluarkan dari unsur tindak pidana dan ditempatkan sebagai faktor yang menentukan dalam pertanggungjawaban pidana. Namun demikian, bagaimana konsep ini diterapkan dalam praktik hukum perlu elaborasi yang lebih mendalam. Di satu sisi, pertanggungjawaban pidana terutama dipandang sebagai bagian dari implementasi tugas hakim dalam memeriksa, mengadili dan memutus perkara yang ada padanya. Oleh sebab itu, hal pertama dalam mengelaborasi mengenai teori pemisahan tindak pidana dan pertanggungjawaban pidana, dengan menelusuri penerapan dan perkembangannya dalam praktek tugas hakim dalam menjatuhkan putusan. Artinya, wujud kongkrit dalam penerapan teori ini secara praktis dapat dilihat kepada tugas hakim dalam menjatuhkan putusan tersebut di pengadilan.

Hal ini dapat diamati dalam RKUHP yang menegaskan pemisahan tindak pidana dan pertanggungjawaban pidana. Konsekuensinya, seluruh tindak pidana hanya merumuskan perbuatan-perbuatan objektif yang dilarang sebagaimana tercantum dalam ketentuan khusus, sedangkan pertanggungjawaban pidana dirumuskan dalam ketentuan umum. Kendati demikian, RKUHP tidak menerapkan teori pemisahan tindak pidana secara konsisten karena

\footnotetext{
${ }^{23}$ George P. Flecther, Op.Cit., hlm. 458.

${ }^{24}$ Paul Robinson. "Rules of Conduct and Principle of Adjudication”. 57 U. Chi. L. Rev hlm. 732-733, (1990). Dalam beberapa tulisannya, Paul Robinson menggunakan dua terminologi berbeda dengan menggambarkan fungsi tindak pidana dan pertanggungjawaban pidana. Untuk fungsi tindak pidana, Robinson menggunakan istilah rules of conduct dan rule of articulation. Adapun untuk pertanggungjawaban pidana, Robinson menggunakan istilah conduct rule untuk menggambarkan fungsi tindak pidana dan decision rule untuk pertanggungjawaban pidana. Secara substantif, Robinson dan Cohen mempunyai kesamaan pendapat terhadap kedua fungsi tersebut.

${ }^{25}$ Meir Dan-Cohen. Decision Rules and Conduct Rules: On Accoustic Seperation in Criminal Law, 97 Harv L Rev 625 (1984) reprinted in Meir Dan-Colen. Harmful Thought: Essay on Law, Self and Morality (Princenton \& Oxford: Princenton University Press, 2002), hlm. 37-94.
} 
Implementasi Teori Dualistis Hukum Pidana Di Dalam Rancangan Kitab Undang-Undang Hukum Pidana (RKUHP) Lukman Hakim

RKUHP masih merumuskan unsur subjektif dalam tindak pidana yang dilakukan dengan kealpaan. Kealpaan seharusnya diatur dalam ketentuan umum disertai dengan catatan bahwa kealpaan hanya diterapkan terhadap tindak pidana tertentu. ${ }^{26}$

Pandangan para ahli hukum pidana terkait konsep monisme dan dualisme terdeskripsi dari pemberian definisi mereka terhadap 'tindak pidana'. J.E. Jonkers merumuskan peristiwa pidana sebagai "perbuatan yang melawan hukum (wederrechttelijk) yang berhubungan dengan kesengajaan atau kesalahan yang dilakukan oleh orang yang dapat dipertanggungjawabkan". ${ }^{27}$ Sementara H.J. van Schravendijk mendefinisikan tindak pidana adalah "kelakuan orang yang begitu bertentangan dengan keinsyafan hukum sehingga kelakuan itu diancam dengan hukuman, asal dilakukan oleh seorang yang karena itu dapat dipersalahkan". ${ }^{28}$ Selanjutnya Van Hamel mengartikan strafbaar feit sebagai "kelakuan orang yang di rumuskan dalam wet, yang bersifat melawan hukum, yang patut dipidana dan dilakukan dengan kesalahan". ${ }^{29}$ Simmons mengatakan bahwa Strafbaarfeit itu adalah "kelakuan yang diancam dengan pidana, bersifat melawan hukum, dan berhubungan dengan kesalahan yang dilakukan oleh orang yang mampu bertanggungjawab" ${ }^{30}$. Secara implisit maupun eksplisit, pandangan para ahli hukum pidana ini dapat dimaknai sebagai penerima ajaran monisme.

Sifat melawan hukum dan kesalahan dalam hukum pidana yang berlaku di Indonesia, khususnya KUHP yang sampai sekarang masih berlaku menganut teori monistis yang menyatakan bahwa sifat melawan hukum (wederrechtelijkheid) dan kesalahan (schuld) merupakan unsur tindak pidana (strafbaar feit). ${ }^{31}$

Di dalam perkembangannya, KUHP tidak menjelaskan hubungan pertanggungjawaban pidana dengan pembuat, tetapi pertanggungjawaban pidana hanya disinggung berkaitan dengan alasan pemaaf dan alasan pembenar yang merupakan bagian dari peniadaan pidana. Sebagaimana terdapat dalam Pasal 44, 48, 49, 50, dan 51 KUHP.

Beberapa ahli hukum pidana yang tidak sependapat dengan teori monistis, berpendapat keadaan hukum pidana di Belanda dan Indonesia terjadi kejanggalan, meskipun kesalahan sebagai sifat mutlak bagi pertanggungjawaban pidana, tetapi dalam praktik

\footnotetext{
${ }^{26}$ M. Ainul Syamsu. Pergeseran Turut Serta Melakukan Dalam Ajaran Penyertaan (Jakarta: Prenadamedia Group, 2014), hlm. 26.

${ }^{27}$ Adami Chazawi. Pelajaran Hukum Pidana (Bagian 1) (Jakarta:Rajawali Pers, 2012), hlm. 75.

${ }^{28}$ Ibid

${ }^{29}$ Moeljatno, Asas-asas Hukum Pidana, Op.Cit., hlm. 61

${ }^{30}$ S.R. Sianturi. Asas-asas Hukum Pidana di Indonesia dan Penerapannya (Jakarta: Alumni AHAEMPETEHAEM, 1996), hlm. 205.

${ }^{31}$ A.Z. Abidin. Hukum Pidana I, cet. II (Jakarta: Sinar Grafika, 2007), hlm. 346.
} 
kesengajaan dan kealpaan masing-masing dianggap sebagai unsur tindak pidana (strafbaar feit), dan bukan unsur pertanggungjawaban pidana. Untuk membentuk kitab undang-undang dalam bahasa Indonesia, yang tidak akan mengukuhi terus sistem yang digunakan dalam WvS terhadap unsur kesengajaan, oleh karena dalam teks Belanda tempatnya kesengajaan di dalam kalimat rumusan undang-undang, mempunyai arti tertentu berhubungan dengan soal kesengajaan (welke element worden door het opzet beheerst), tempat mana tentu tidak dapat dipertahankan. ${ }^{32}$

Pandangan yang memisahkan tindak pidana dengan pertanggungjawaban pidana, yaitu unsur utama dari pertanggungjawaban pidana hanyalah unsur kesalahan, dan kesalahan bukan sebagai unsur dari tindak pidana ini dikenal sebagai teori/asas dualistis. Ahli hukum pidana yang pertama kali yang mengemukakan teori dualistis adalah Herman Kantorowicz, seorang sarjana hukum pidana Jerman yang menulis buku yang berjudul Tut und Schuld pada tahun $1933 .{ }^{33}$ Pandangan Moeljatno yang mengikuti pendapat Herman Kantorowicz ini banyak diikuti dan dikembangkan oleh ahli hukum pidana Indonesia di antaranya Roeslan Saleh, A. Z. Abidin, Barda Nawawi Arief dan Chairul Huda. Teori dualistis selain dipengaruhi oleh hukum pidana Jerman, juga banyak dipengaruhi oleh sistem hukum pidana yang dipakai oleh negara-negara Eropa Anglo Saxon yang mengunakan common law system.

Adapun definisi tindak pidana menurut Naskah Akademis RKUHP adalah perbuatan melakukan atau tidak melakukan sesuatu yang oleh peraturan perundang-undangan dinyatakan sebagai perbuatan yang dilarang dan diancam dengan pidana. Untuk dinyatakan sebagai tindak pidana, selain perbuatan tersebut dilarang dan diancam pidana oleh peraturan perundang-undangan, harus juga bersifat melawan hukum atau bertentangan dengan kesadaran hukum masyarakat. ${ }^{34}$

Dasar untuk menyatakan suatu perbuatan sebagai tindak pidana atau bukan bertolak dari asas legalitas formal, namun demikian juga memberi tempat kepada hukum yang hidup/hukum tidak tertulis sebagai sumber hukum, rambu-rambunya yaitu sepanjang sesuai dengan nilai-nilai Pancasila dan/atau prinsip-prinsip hukum umum yang diakui oleh masyarakat bangsa-bangsa (nilai-nilai nasional dan internasional). Sesuai dengan nilai-nilai nasional yaitu Pancasila. Artinya sesuai dengan nilai paradigma moral religius, nilai kemanusiaan, kebangsaan, demokrasi, dan nilai-nilai keadilan sosial. Sedangkan nilai-nilai

\footnotetext{
32 Ibid., hlm. 29.

${ }^{33}$ Muladi, Dwidja Priyatno. Pertanggungjawaban Pidana Korporasi (Jakarta: Kencana Prenada Media Group, 2010), hlm. 64.

${ }^{34}$ Naskah Akademis RKUHP, Op.Cit., hlm. 255.
} 
Implementasi Teori Dualistis Hukum Pidana Di Dalam Rancangan Kitab Undang-Undang Hukum Pidana (RKUHP) Lukman Hakim

internasional adalah mengacu/bersumber dari istilah "the general principle of law recognized by the community of nations" yang terdapat dalam Pasal 15 ayat (2) ICCPR (International Covenant on Civil and Political Right). ${ }^{35}$

Pada dasarnya, RKUHP menganut teori dualistis sebagaimana tergambar pada Pasal 12 ayat (1) RKUHP yang mengatur bahwa, "Tindak pidana adalah perbuatan melakukan atau tidak melakukan sesuatu, yang oleh peraturan perundang-undangan diancam dengan pidana”. Selanjutnya di dalam Pasal 12 ayat (2) RKUHP dinyatakan, "Untuk dinyatakan sebagai tindak pidana, suatu perbuatan yang diancam pidana oleh peraturan perundang-undangan harus juga bersifat melawan hukum atau bertentangan dengan hukum yang hidup dalam masyarakat”. Hal mana selanjutnya di dalam Pasal 12 ayat (3) RKUHP dinyatakan, "Setiap tindak pidana selalu dipandang bersifat melawan hukum, kecuali ada alasan pembenar".

Hal di atas semakin dipertegas dengan meletakkan rumusan pertanggungjawaban pidana dan kesalahan di dalam RKUHP tersebut. Di dalam Pasal 37 RKUHP dinyatakan, "Pertanggungjawaban pidana adalah kondisi terpenuhinya celaan yang objektif dan celaan yang subjektif untuk dapat dipidananya seseorang yang telah melakukan tindak pidana”. Di mana selanjutnya berdasarkan Pasal 38A dinyatakan, "Pertanggungjawaban pidana meliputi unsur kemampuan bertanggung jawab, kesengajaan atau kealpaan, dan tidak ada alasan pemaaf”. Adapun ketentuan mengenai "Kesalahan” diatur di dalam Pasal 38 RKUHP yang berbunyi, "Tidak seorang pun yang melakukan tindak pidana dapat dipertanggungjawabkan tanpa adanya kesalahan”.

Ketentuan di atas sejalan dengan RKUHP yang ada di dalam Naskah Akademik yang menfokuskan kepada 3 (tiga) masalah pokok dalam hukum pidana, yaitu tindak pidana, pertanggungjawaban pidana, serta pidana dan pemidanaan. Masing-masing merupakan subsistem dan sekaligus pilar-pilar dari keseluruhan bangunan sistem pemidanaan.

Dengan adanya rumusan asas perbuatan dan pembuatnya/pelakunya, yaitu asas yang mendasarkan kepada apa yang dilakukan dan siapa yang melakukannya, maka tindak pidana dan pertanggungjawaban pidana memperoleh pengaturan yang jelas. Adapun yang dimaksud dengan pertanggungjawaban pidana adalah diteruskannya celaan yang secara objektif ada pada tindak pidana berdasarkan ketentuan hukum yang berlaku, dan secara subjektif kepada pembuat yang memenuhi syarat dalam undang-undang (pidana) untuk dapat dikenai pidana karena perbuatannya. ${ }^{36}$

\footnotetext{
35 Ibid.

${ }^{36}$ Ibid., hlm. 29.
} 
Dengan diteruskannya celaan yang objektif ada pada tindak pidana berdasarkan ketentuan yang berlaku dan yang secara subjektif kepada pelaku yang memenuhi syaratsyarat dalam undang-undang (pidana) untuk dapat dipidana karena perbuatannya itu, maka timbullah hal pertanggungjawaban pidana. Masalahnya, apakah pelaku dapat dicela dengan dilakukannya perbuatan yang dilarang tersebut? Apabila dapat, maka berarti ia dapat dipidana, dalam hal dapat dibuktikan kesalahannya, baik dalam arti sengaja atau tidak karena kealpaannya. ${ }^{37}$

Seseorang dikatakan bersalah apabila ia dapat dicela dipandang dari sudut kemasyarakatan, sebab ia dianggap semestinya dapat berbuat lain jika ia memang tidak ingin berbuat demikian, sedang yang dimaksud dengan kesalahan ialah keadaan jiwa seseorang yang melakukan perbuatan itu dalam hubungannya dengan perbuatannya, dan hubungan itu sedemikian hingga ia dapat dicela atas perbuatan tersebut. ${ }^{38}$

Konsekwensi logis dari hal di atas, maka setiap tindak pidana selalu dilakukan dengan kesengajaan, kecuali tindak pidana tertentu yang dilakukan dengan kealpaan. Untuk membedakan tindak pidana yang dilakukan dengan sengaja dan kealpaan, RKUHP mengatur unsur kesengajaan tidak perlu dicantumkan dalam rumusan tindak pidana, yang dicantumkan dalam rumusan tindak pidana hanya unsur kealpaan, karena telah diatur dalam Pasal 40 ayat (2) RKUHP bahwa setiap tindak pidana dilakukan dalam kesengajaan kecuali undang-undang menentukan secara tegas bahwa suatu tindak pidana dilakukan dengan kealpaan.

Apabila pengaturan di atas dipikirkan lebih lanjut, dalam pemeriksaan di persidangan dapat menimbulkan implikasi, yaitu penuntut umum tidak perlu lagi membuktikan unsur kesengajaan, karena unsur kesengajaan tidak tercantum secara tegas dalam rumusan tindak pidana. Apabila mengikuti pendapat dualistis, yang dicantumkan hanya unsur kealpaan akan beriplikasi terjadinya perbedaan kualifikasi. Apabila unsur kealpaan yang tercantum secara eksplisit itu tidak terbukti, maka akan mengakibatkan putusan yang menyatakan pembuat dibebaskan (vrisjpraak). Unsur kesengajaan yang tidak tercantum secara eksplisit dalam rumusan tindak pidana, dan unsur kesengajaan sebagai unsur pertanggungjawaban tidak terbukti, akan mengakibatkan pembuat dinyatakan lepas dari segala tuntutan hukum (ontslag van alle rechtsvervolging). ${ }^{39}$

\footnotetext{
37 Ibid.

${ }^{38}$ Ibid.

39 Ibid.
} 
Implementasi Teori Dualistis Hukum Pidana Di Dalam Rancangan Kitab Undang-Undang Hukum Pidana (RKUHP) Lukman Hakim

Sekalipun demikian, usaha tersebut harus terus menerus dikembangkan sehingga manfaatnya dapat lebih komprehensif sejalan dengan pandangan Andi Hamzah, "pemisahan tersebut hanya penting diketahui oleh penuntut umum dalam penyusunan surat dakwaan, karena surat dakwaan cukup berisi bagian inti (bestandeel) delik dan perbuatan nyata terdakwa, jadi actus reus saja." ${ }^{40}$ Mengingat pendapat di atas, maka dengan sendirinya juga sangat penting bagi penasihat hukum untuk menyusun pembelaan. Pada gilirannya Hakim juga perlu untuk memahami konsep ini dalam menyusun putusan.

Secara ideal, pengadilan adalah tempat untuk mendapatkan keadilan. Hal mana secara praktis, pengadilan adalah tempat untuk memisahkan orang yang bersalah dan tidak bersalah. Namun kenyataannya tidak selalu sejalan dengan gagasan normatifnya. Tidak selamanya Hakim memiliki kesadaran di dalam hatinya bahwa kelak ia akan mempertanggungjawabkan hasil pekerjaannya di hadapan Tuhan Yang Maha Esa. Lebih lanjut, seringkali menurut pandangan sebagian besar masyarakat didapati putusan-putusan Hakim yang tidak mencerminkan rasa keadilan. Sistem peradilan pidana justru tempat maraknya "kriminalisasi" terhadap kebijakan, serta jual beli perkara, bahkan juga tidak jarang sering terjadi pelanggaran terhadap hak asasi manusia.

Secara faktual, banyak perkara pidana yang sebenarnya "tidak layak" diajukan ke pengadilan, terutama apabila dihadapkan dengan perkembangan aspek sosial, aspek ekonomi dan aspek budaya dalam masyarakat yang majemuk dan berbagai kepentingan dan kebutuhan yang berbeda-beda. Hal ini antara lain dikarenakan nilai kerugian yang terlalu kecil, ataupun menyangkut persoalan-persoalan sepele, ataupun pelaku-pelaku yang seharusnya mendapat perlakuan khusus (younger and older offender), ataupun ataupun perkara-perkara dengan ancaman di atas 5 (lima) tahun yang bertentangan dengan nilai-nilai kemanusiaan dan keadilan yang hidup di masyarakat dan sebenarnya perlu dicarikan jalan lain dalam penyelesaiannya.

Dikaitkan dengan teori dualistis di atas, maka dalam hal penjatuhan pidana, pengadilan bertugas memberikan pertimbangan secara seimbang antara tindak pidana dan pertanggungjawaban pidana pembuat tindak pidana sebagai dasar penjatuhan pidana. Di satu sisi, tindak pidana menegaskan kepentingan hukum masyarakat yang hendak dilindungi oleh norma hukum. Di sisi lain, kesalahan dan pertanggungjawaban pidana menekankan kepada kewajiban hukum yang didasarkan atas keadaan tertentu pada diri pembuat tindak pidana.

\footnotetext{
${ }^{40}$ Andi Hamzah, Op.Cit., hlm. 90.
} 
Namun demikian, tampak dari beberapa putusan pengadilan bahwa pekerjaan mengadili hanya dipandang sebagai perbuatan mengadili yang hanya mengedepankan rumusan delik semata dan mengabaikan asas hukum pidana yang ada yang mendasarinya. Tugas "mulia" Hakim dalam hal mengadili dianggap telah selesai ketika perbuatan (objektif dan subjektif) terdakwa telah mencocoki seluruh rumusan delik, tanpa mengelaborasi lebih jauh apakah perbuatan yang didakwakan benar-benar bertentangan dengan kepatutan dalam masyarakat dan apakah keadaan terdakwa senyatanya layak untuk dijadikan sebagai dasar penjatuhan pidana.

Begitu pula perhatian dan suara masyarakat terhadap lembaga dan aparatur penegak hukum sangat keras pada pasca reformasi, khususnya berkenaan dengan masalah hukum yang menyangkut hajat masyarakat, bangsa dan negara. Seiring dengan pemberitaan di berbagai media massa tentang dukungan masyarakat terhadap penegakan hukum, tetapi juga kekecewaan dan kecaman masyarakat terhadap penegakan hukum, baik oleh kepolisian, kejaksaan maupun pengadilan. ${ }^{41}$

Kekecewaan masyarakat muncul karena tidak terpenuhinya harapan terhadap pengadilan untuk mewujudkan kebenaran, keadilan disamping juga terwujudnya ketentraman dan kemaslahatan. ${ }^{42}$ Hingga saat ini sebagian masyarakat percaya bahwa pengadilan sebagai benteng terakhir mencari keadilan. ${ }^{43}$ Tetapi, kepercayaan masyarakat berbanding terbalik dengan dengan fakta keterpurukan pengadilan. Keterpurukan pengadilan tersebut bertentangan dengan "fitrah" keberadaan lembaga peradilan sebagai salah satu sarana untuk menyelesaikan konflik hukum. ${ }^{44}$ Oleh karenanya, tidak heran Hakim dipandang sebagai corong undang-undang. Padahal tugas "mulia" Hakim seharusnya lebih jauh dari itu. Hal ini sejalan dengan Pasal 14 ayat (2) Undang-Undang Dasar Sementara (UUDS) 1950 yang berbunyi: Tiada seorang juapun boleh dituntut untuk dihukum atau dijatuhi hukuman, kecuali karena aturan hukum yang sudah ada dan berlaku

\footnotetext{
41 "Koin keadilan: Ketika Keadilan direcehkan Kitapun Mengumpulkan Receh", (On-Line), tersedia di:http://koinkeadilan.com (29 Desember 2018). Sebagai indikasi dari proposisi ini bermunculannya gerakangerakan sosial untuk turut serta mendorong penegakan hukum yang fair. Gerakan koin keadilan untuk kasus Prita setidaknya menjadi salah satu gerakan yang mewakili kekecewaan publik terhadap penegakan hukum.

${ }^{42}$ Abdul Ghafur Anshori, Zulkarnain Harahap. Hukum Islam dan Perkembangannya di Indonesia (Yogyakarta: Kreasi Total Media, 2008), hlm. 31. Kemaslahatan merupakan prasyarat dari tercapainya kebahagiaan. Kebahagiaan bagian yang tidak terpisahkan dari tujuan hukum. Konsep kemaslahatan lebih dikenal dalam terminologi hukum Islam dengan istilah maqashidus syari'ah yaitu tujuan-tujuan diberlakukannya syariat Islam.

43 Adi Sulistiyono. "Menggapai Mutiara Keadilan: Membangun Pengadilan yang Independen dengan Paradigma Moral”. (Jurnal Ilmu Hukum, Vol. 8, No 2, September, 2005), hlm. 152.

${ }^{44}$ Fungsi utama pengadilan adalah untuk menyelesaikan konflik.
} 
Implementasi Teori Dualistis Hukum Pidana Di Dalam Rancangan Kitab Undang-Undang Hukum Pidana (RKUHP) Lukman Hakim

terhadapnya. ${ }^{45}$ Istilah aturan Hukum (Recht) yang tentu lebih luas pengertiannya dari sekedar aturan "undang-undang" (wet), karena pengertian "hukum" (recht) dapat berbentuk "hukum tertulis" maupun "hukum tidak tertulis".

Dari gambaran di atas, ada hal yang perlu dikemukakan, bahwa berdasarkan asas legalitas, di dalam perspektif penegak hukum, mungkin tidak ada yang salah dalam penjatuhan putusan pemidanaan di atas, artinya apapun isi putusan pengadilan selama Hakim dalam memutuskannya berkeyakinan telah mendasarkan diri pada hukum positif yang ada maka dapat dikatakan telah sah secara hukum.

Dengan diterapkannya teori dualistis dalam RKUHP yang akan datang, maka diharapkan sistem pemidanaan akan menjadi lebih seimbang antara kepastian hukum dan keadilan yang muncul dari putusan hakim dalam perkara pidana.

\section{PENUTUP}

\section{A. Simpulan}

Keberadaan asas legalitas di dalam sistem hukum pidana di Indonesia, khususnya dalam KUHP memiliki posisi yang signifikan dalam sistem peradilan pidana, di mana sifat melawan hukum (wederrechtelijkheid) dan kesalahan (schuld) merupakan unsur dari tindak pidana (strafbaar feit) atau yang lebih dikenal dengan ajaran monistis. KUHP tidak menjelaskan hubungan pertanggungjawaban pidana dengan pembuat, tetapi pertanggungjawaban pidana hanya disinggung semata-mata berkaitan dengan alasan pemaaf dan alasan pembenar. Akibatnya banyak permasalahan yang terjadi di dalam sistem peradilan pidana, di mana para penegak hukum lebih mengutamakan kepastian hukum dari pada keadilan. Sementara dalam doktrin hukum pidana, dikenal "asas tiada pidana tanpa kesalahan" atau lebih dikenal dengan teori dualistis. Pada pokoknya ajaran ini memisahkan tindak pidana dan pertanggungjawaban pidana. Tindak pidana hanya menyangkut persoalan 'perbuatan', sedangkan masalah apakah 'orang' yang melakukan perbuatan tersebut kemudian dapat dipertanggungjawabkan, adalah persoalan yang berbeda. Dalam konteks ini, teori dualistis memiliki peran yang sangat signifikan guna mengatasi kekakuan permasalahan dalam sistem peradilan pidana, utamanya bagi para penegak hukum. Sehingga

\footnotetext{
45 Moeljatno. Asas-asas Hukum Pidana (Jakarta: Rineka Cipta, 2008), hlm. 28. Moeljatno mengatakan, "Dengan demikian, juga untuk berlakunya hukum pidana adat diberikan dasar yang kuat. Meskipun sekarang UUD sementara sudah tidak berlaku lagi, namun hemat saya, dari bunyinya pasal 5 ayat 3b Undang-Undang Darurat 1951 No. 1, di atas, kiranya tidak seorang pun yang akan menyanggah sahnya ketentuan tersebut berdasar tidak berlakunya Pasal 14 Ayat 2 UUD Sementara tadi”.
} 
ketika terjadi benturan antara kepastian hukum dan keadilan, maka yang harus diutamakan adalah keadilan.

\section{DAFTAR PUSTAKA}

Kitab Undang-Undang Hukum Pidana.

Kitab Undang-Undang Hukum Acara Pidana.

Abidin, A.Z. Hukum Pidana I, cet. II. Jakarta: Sinar Grafika, 2007.

Alf Ross. On Guilt, Responsibility and Punishment. London: Stevens and Sons, 1975.

Anshori, Abdul Ghafur., Zulkarnain Harahap. Hukum Islam dan Perkembangannya di Indonesia. Yogyakarta: Kreasi Total Media, 2008.

Arief, Barda Nawawi. Kapita Selekta Hukum Pidana. Bandung: Citra Aditya Bakti, 2013.

Chazawi, Adami. Pelajaran Hukum Pidana (Bagian 1). Jakarta:Rajawali Pers, 2012.

Curzon, L. B. Criminal Law. London: M\&E Pitman Publishing, 1997.

Dan-Cohen, Meir. Decision Rules and Conduct Rules: On Accoustic Seperation in Criminal Law, 97 Harv L Rev 625 (1984) reprinted in Meir Dan-Colen. Harmful Thought: Essay on Law, Self and Morality. Princenton \& Oxford: Princenton University Press, 2002.

Ernest Ludwig von Beling. Lehre vom Verbrechen. Tubingen: JCB Mohr, 1906.

Eser, Albin. "Justification and Excuses" 24. The American Juornal of Comparative Law, 1976.

Flecther, George P. Rethinking Criminal Law. New york: Oxford University Press, 2000.

Hamzah, Andi. Asas-Asas Hukum Pidana. Jakarta: Penerbit Rineka Cipta, 2014.

Moeljatno. "Perbuatan Pidana dan Pertanggungjawaban Dalam Hukum Pidana". (Pidato Ilmiah dalam Dies Natalis Universitas Gajah Mada, pada tanggal 19 Desember 1955).

Muladi, Dwidja Priyatno. Pertanggungjawaban Pidana Korporasi. Jakarta: Kencana Prenada Media Group, 2010.

-------, Barda Nawawi Arief. Teori-teori dan Kebijakan Pidana. Bandung: Alumni, 1984.

"Prinsip-individualisasi-pidana", (On-line), tersedia di:http://ahmadbahiej.blogspot.co.id.2003/08 (8 Agustus 2017).

Packer, Herbert L. The Limits of The Criminal Sanction. Stanford California University: Stanford California Press, 1968.

Robinson, Paul. “Rules of Conduct and Principle of Adjudication”. 57 U. Chi. L. Rev 1990. 
Implementasi Teori Dualistis Hukum Pidana Di Dalam Rancangan Kitab Undang-Undang Hukum Pidana (RKUHP) Lukman Hakim

Saleh, Roeslan. Masih Saja tentang Kesalahan. Jakarta: Karya Dunia Fikir, 1994.

-------. Perbuatan Pidana dan Pertanggungjawaban Pidana; Dua Pengertian Dasar dalam Hukum Pidana. Jakarta: Aksara Baru, 1983.

Sianturi, S.R. Asas-asas Hukum Pidana di Indonesia dan Penerapannya (Jakarta: Alumni AHAEM-PETEHAEM, 1996.

Sulistiyono, Adi. "Menggapai Mutiara Keadilan: Membangun Pengadilan yang Independen dengan Paradigma Moral”. Jurnal Ilmu Hukum, Vol. 8, No 2, September, 2005.

Syamsu, M. Ainul. Pergeseran Turut Serta Melakukan Dalam Ajaran Penyertaan. Jakarta: Prenadamedia Group, 2014.

William, Glanvile. Criminal Law: Generel Part. London: Stevens \& Sons, 1961.

Tim Penyusun. "Naskah Rancangan Kitab Undang-Undang Hukum Pidana Hasil Pembahasan Panitia Kerja RKUHP-DPR RI", 24 September 2018. Jakarta: BPHN \& Menkumham, 2018.

Tim Penyusun. "Naskah Akademis Rancangan Kitab Undang-Undang Hukum Pidana (RKUHP) Edisi 25 Februari 2015”. Jakarta: BPHN \& Menkumham, 2015.

"Koin keadilan: Ketika Keadilan direcehkan Kitapun Mengumpulkan Receh”, (On-Line), tersedia di:http://koinkeadilan.com (29 Desember 2018).

(On-line), tersedia di:http://firmanhakim03.blogspot.com/2016/09/rangkuman-keteranganahlipidana-prof-26-html (7 Oktober 2017). 